\title{
Corrigendum: Assembly of a conduct risk regulatory model for developing market banks
}

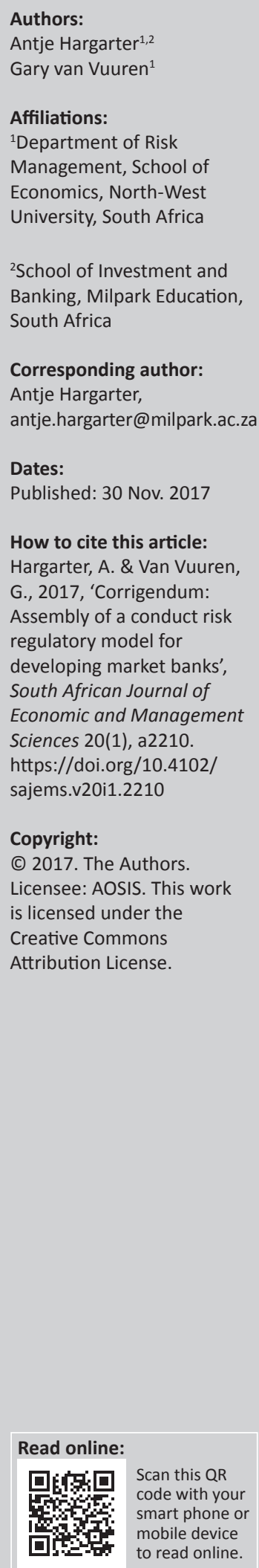

Published: 30 Nov. 2017

How to cite this article: Hargarter, A. \& Van Vuuren, G., 2017, 'Corrigendum: Assembly of a conduct risk regulatory model for developing market banks', South African Journal of Economic and Management Sciences 20(1), a 2210 . https://doi.org/10.4102/ sajems.v20i1.2210

Copyright:

(C) 2017. The Authors. Licensee: AOSIS. This work is licensed under the Creative Commons Attribution License.

In the version of this article initially published, Antje Hargarter's first affiliation was omitted. Her first affiliation is the Department of Risk Management, School of Economics, North-West University, South Africa. The error has been corrected in the PDF version of the article. The author apologises for any inconvenience that this omission may have caused. 


\section{Assembly of a conduct risk regulatory model for developing market banks}

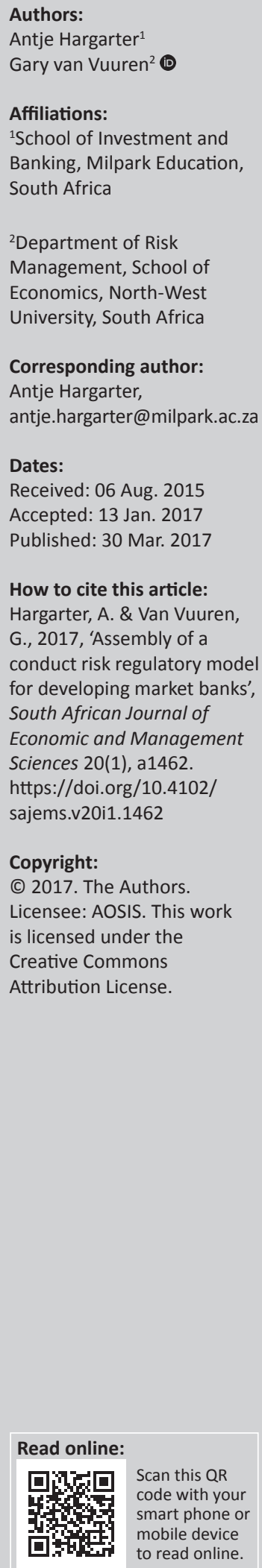

Background: The substantial penalties imposed on banks in the recent past for various conduct irregularities have given rise to a new type of risk called conduct risk. Conduct risk comes about when financial services companies conduct themselves in an inappropriate way towards their customers, resulting in a negative (economic) outcome for the customer. What makes the management and mitigation of conduct risk by banks so different is that it cannot be easily integrated into a bank's standard risk management framework. So far, the concept of conduct risk has not been formally covered by the Basel Accords.

Aim: There are, however, global efforts by international organisations and local regulators to control it - with little clarity on the 'how'. The aim of this study is to explore this 'how'.

Setting: While regulators need to protect customers, resulting in a positive outcome for the customer, they must also ensure that banks take conduct risk management and its mitigation seriously. At the same time, any regulatory model for conduct risk needs to be incorporated into the existing bank regulatory strategy and methodology and assimilated with the profile of a country.

Methods: An exploratory model that regulators could use to keep conduct risk at bay is developed based on primary and secondary data and this is then applied to the South African, Kenyan and Malaysian milieus to determine what can be learnt about conduct risk in emerging economies.

Results: The model investigates the interrelationships between different goals that regulators ideally need to achieve and the findings show that regulators have a difficult task balancing these goals and at the same time achieving a positive outcome.

Conclusion: Based on the model, the recommendation for regulators in the developing world would be to collaborate in their approach to conduct risk, as they might face similar difficulties and operate in a comparable context.

\section{Introduction}

Banking can be traced back to the 18th century BC when the first records of loans were found (Gascoigne 2001). Banking institutions fund themselves with public deposits, and they then lend out these funds to debtors. This is one of the reasons that the regulation of banks, more so than other industries, is crucial. The Bank for International Settlement's Basel Committee on Banking Supervision (the BCBS) works globally to establish minimum global regulatory and supervisory standards, with the goal of enhancing financial stability (BIS 2014). The risks covered by the various iterations of the so-called Basel Accords (I, II and III) are credit, operational and market risk - liquidity risk was recently added (BCBS 2006, 2011). The concept of conduct risk has not been formally covered by the Basel Accords. There are, however, global efforts by international organisations and local regulators to control it. Conduct risk surfaced after the global financial crisis of 2008/2009 (National Treasury 2011). One example that highlights how important the concept of conduct risk has become globally is that the Organisation for Economic Cooperation and Development (OECD) expects all its members to integrate conduct risk into their regulatory approach (OECD 2011, 2013). In the standard approach to risk management, banks ask whether the risk is within appetite, whereas in the approach to conduct risk, banks ask how a scenario will look when risk appetite is breached (Management Solutions 2016). Because the approach is slightly different, this new type of risk cannot be covered under operational risk only; it needs to be added to the general risk framework of banks and managed and mitigated accordingly (Raj and Sindhu 2013). In the last 3 years, many banks have received considerable fines based on conduct failure (FCA 2015). As part of the EU-wide 2016 stress test, banks had to forecast operational risk losses using their internal models. Fifteen European banks estimated the 
aggregate potential loss from conduct risk to be 71 billion Euros for 2016-2018 (CCP 2016).

This article presents the necessary background to the topic of conduct risk regulation for banks. A model is then constructed to show how regulation should be approached by the regulator in order to ensure effective market conduct regulation. Case studies of developing countries are used to indicate whether such a model could be successful. In most countries, conduct risk regulation has either not been implemented at all or not for an extensive period. This research will provide direction, rather than pinpointing exact results.

This article is organised as follows. The 'Introduction' section presents an introduction to the concept of conduct risk and related concepts. The 'Literature review' section covers the literature review. Assembling an appropriate banking conduct regulatory model is covered in the 'Constructing an effective model for banking conduct risk regulation in developing countries' section, and the model is then tested in the 'Testing the model: Specific developing country examples' section. The 'Conclusion and recommendations' section provides a conclusion as to whether the proposed model could work, as well as recommendations for furthering this research.

\section{Definitions}

Conduct risk, from a bank's point of view, is defined as '... the risk that detriment is caused to the bank, [our] customers, clients or counterparties because of the inappropriate execution of [our] business activities' (Barclays 2012:189). A distinction should be made between the conduct of business and financial market integrity, sometimes referred to as retail versus wholesale conduct risk (National Treasury 2014).

Regulators differentiate between market conduct and consumer empowerment/protection. Within market conduct, the focus is on the institutional framework and supervision, sales and marketing practices, fees and charges, lack of transparency and disclosure and responsible lending; whereas in terms of consumer empowerment/protection, the focus is on consumer financial literacy and awareness and avenues for help and redress (Alliance for Financial Inclusion 2015).

For the purpose of this research, effective bank conduct risk regulation means the following: the bank conduct risk regulation model is developed, with consideration to all relevant influencing criteria, and leads to a situation where banks are compliant (manage and mitigate conduct risk according to the laws and regulations set out). As a result, the outcome for customers is positive in the sense that they receive financial products/services that suit their needs. It should be mentioned at this point that the measurement of this outcome is challenging.

The term 'customer' is used to refer to the client of a bank. The term 'consumer' is used in the context of consumer protection and education across industries.

\section{Research philosophy, question and relevance}

The research methodology suggested for this type of research is inductive and exploratory (Trochim 2006), as a model is developed that could constitute a new approach/ theory. The main research question is: which influencing factors should regulators in developing countries take into consideration when constructing a (country-specific) regulatory approach for conduct risk in the banking sector in order to ensure that conduct risk is managed and mitigated by the banks in a way in which the outcome for customers will be positive?

This research will help stakeholders understand banking conduct risk regulation as a new concept and how it can be implemented successfully in developing countries to the benefit of both the customer and the bank.

\section{Literature review}

\section{Bank regulation as a necessity}

Banks have to comply with more specific laws and regulations than companies from other sectors:

It is likely that, in the absence of prudential regulation, deposittakers, insurers and investment firms would be less resilient against failure, and risk more disruption to the continuity of financial services, than is in the public interest. (Bank of England 2012:5)

However, 'it is an illusion to believe that there is a single, superior model of institutional structure that is applicable to all countries' (Llewellyn 2006:7). In addition to other criteria, the structure of the banking sector and the financial sector as a whole would need to play a role in the selection of a suitable model (Sum 2016).

Another topic of interest is the question of whether institutions or financial products should be regulated by the same entity. For example, in South Africa, the market conduct authority will in future be responsible for regulating how banks design and price their products; however, the prudential supervisor also needs to ensure that the financial products that are sold are consistent with prescribed principles, even though their focus is on the supervision of institutions (National Treasury 2013). This may prove challenging if both entities do not work together closely.

\section{Prudential regulation versus market conduct regulation}

Within bank supervision and regulation, prudential regulation and market conduct regulation can be differentiated. On the one hand, the prudential regulator is typically responsible for ensuring the safety and soundness of banks and minimising the adverse effects that they can have on the stability of the financial system. On the other hand, the market conduct regulator usually ensures that relevant markets function well, and that banks conduct themselves appropriately (Bank of England 2012). Čihák and Podpiera (2008) have discovered that there is some support for the Twin Peaks approach, which integrates supervision across sectors and, 
at the same time, separates business conduct and prudential supervision.

\section{Generally:}

financial consumer protection should be an integral part of the legal, regulatory and supervisory framework, and should reflect the diversity of national circumstances and global market and regulatory developments within the financial sector. (OECD 2011:5)

Dias (2013) also recommends that bank supervisors leverage positions in the existing institutional landscape to advance and add financial consumer protection topics to existing oversight practices. He puts forward a risk-based approach to consumer protection, in line with prudential regulation, to strengthen the banks' existing risk management framework.

When it comes to conduct risk, some countries have regulated credit-related products separately from investment-related products. For example, South Africa introduced the National Credit Act in 2005, to ensure credit providers do not encourage customers to take on loans to the point where they become over-indebted (BASA 2016).

This raises the question of whether there should be a single piece of conduct regulation or not. In many countries, conduct risk spans across various different regulations and is not captured in one piece of regulation.

\section{Bank regulation in different countries}

South Africa as an example of Twin Peaks: After the global financial crisis, and partly on account of the Competition Commission Banking Enquiry (Competition Commission 2008), South Africa decided to change its financial sector legislation and is currently moving towards a new Twin Peaks approach that separates prudential regulation and market conduct regulation. The South African Financial Services Board (SA FSB) has implemented the Treating Customers Fairly (TCF) approach to supervision across the financial services industry in preparation for the new conduct regulation (National Treasury 2014).

The new Financial Sector Regulation (FSR) Bill which the National Assembly voted on in late 2016, prescribes two new authorities - the Prudential Authority (PA) and the Financial Services Conduct Authority (FSCA) - to be established. Until the new Conduct of Financial Institutions Act (CoFi Act) comes into effect (likely to occur in 2017), the FSCA will work with existing laws that already require specific conduct from financial services companies (National Treasury 2015).

Malaysia as an example of non-Twin Peaks: In Malaysia, financial consumer protection and market conduct supervision are the responsibility of the Central Bank, and they need to leverage existing internal synergies. However, there is an internal Twin Peaks structure that promotes 'checks and balances' and a strong focus on safety, soundness and consumer protection objectives. The enforcement function is separated from prudential and conduct supervision and resides with the Financial Intelligence and Enforcement Department of the Bank (Ali 2014).

Other developing banking market examples: Kenya: Kenya follows neither a Twin Peaks nor a One Peak model. The country's current approach is to keep banking supervision separate within the Central Bank of Kenya (CBK), but to integrate both prudential supervision and conduct of business supervision of all the other regulators in the Financial Services Council (Capital Markets Authority Kenya 2014; CBK 2014, 2015).

In 2013, the CBK, as the main banking regulator in Kenya, published a new set of prudential and risk management guidelines, which includes a specific section on consumer protection and a specific section on reputational risk. The CBK is using remedial actions provided for under certain sections of the Banking Act and may take other action as it deems appropriate (CBK 2013a, 2013b).

\section{Financial crises and regulation}

The global financial crisis has resulted in many countries reviewing and reinventing their financial sector policy priorities as a whole (National Treasury 2011). Nichols, Hendrickson and Griffith (2011) suggest that every major financial crisis in the USA has brought about some new legislation, and that the same regulatory response is likely to have an influence on the next financial crisis. Ojo (2010) pointed out a growing global trend in 2010 (after the global financial crisis) towards enforced self-regulation in the sense that regulators no longer prescribe strict rules, but rather encourage firms to use their own approach (meta-risk regulation). Sepe (2012) argues that crises are erroneously held responsible for managerial moral hazard. Instead he recommends a contractarian approach to bank regulation, where '[...] regulators act as debt holders, and [would] offer lower capital requirements and lower deposit insurance premiums while demanding the same governance concessions'. (Sepe 2012:328)

\section{Profitability, sustainability and socioeconomic realities}

'The post-crisis pressure on firms to rebuild prudential soundness, attract new funding and maximise profits could lead to short-sighted strategies that have unintended conduct consequences' (FCA 2013:48). The challenge presented in this statement is particularly important for banks that are operating in developing economies, where consumer protection, financial inclusion and education are more important concepts than in the developed world. The United Nations Environment Programme (UNEP) (2015) is convinced that sustainable behaviour and practice (economic, environmental and social) can drive economic profits.

\section{Culture and other intangible factors that influence regulation}

It would seem as though cultural norms that prevail in certain countries influence the effectiveness of specific 
regulatory approaches. This should be even more distinct when one considers conduct risk, as it is influenced by values and culture. According to Cohen, Pant and Sharp (2001) a strong uncertainty-avoidant culture requires extensive rules and regulations for various situations, while weak uncertainty-avoidant cultures are more tolerant of ambiguity.

Chen, Danbolt and Holland (2014) insist that intangible factors do in fact have relevance for systemic risk and bank regulation. Alemanno (2015) argues that many OECD countries are becoming aware of how important public engagement is in policymaking. Finally, trust between the regulated and regulators is vital for regulation to function effectively (Ugeux 2014).

\section{Customer responsibility and complaints resolution}

The financial crisis:

highlighted the importance of financial consumer protection for the long-term stability of the global financial system. At the same time, rapid increases in the use of financial services have pointed to the need for strengthened financial regulation and consumer education to protect and empower consumers. (The World Bank 2012:1)

This quote makes reference to a consumer who is educated and able to take responsibility for his actions and decisions. However, one of the challenges is that bank customers might not behave rationally with regard to their financial choices at all times (Azis \& Shin 2015).

\section{Constructing an effective model for banking conduct risk regulation in developing countries}

Regulators will try to influence banks' conduct with regard to their complete value chain (Figure 1), from the agenda of top management to product design and after-sales, with the ultimate goal of creating a positive outcome for the customer. Concepts similar to conduct need to be considered when constructing the model, as they may be influencing factors with regard to the outcome the regulator is trying to achieve.

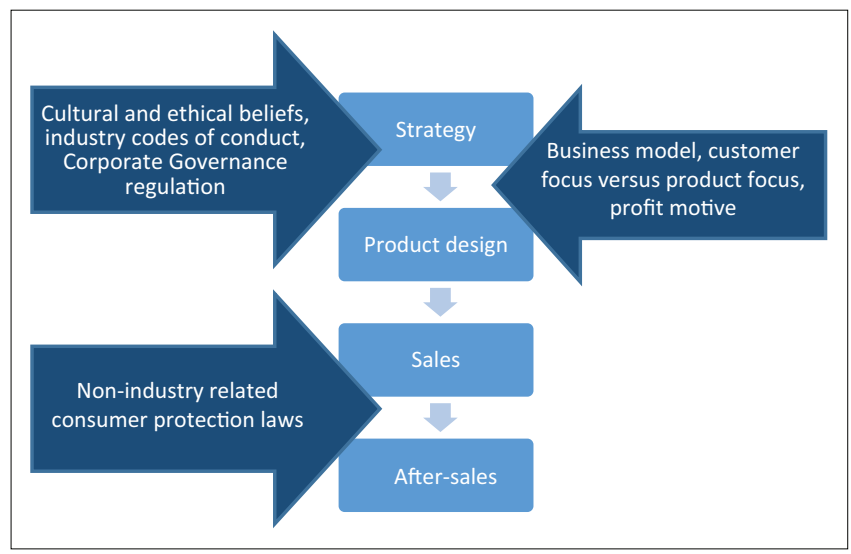

FIGURE 1: Value chain of banks.

\section{Model proposal}

Although regulatory approaches, and the question of whether they are effective, mainly require a qualitative mindset, it is important to explore relationships and interdependencies between different influencing factors (Figure 2).

The end goal of all conduct regulation is that the outcome for the customer should be positive. What exactly does this mean and how will it be measured? A positive outcome for a customer should, at minimum, mean that he has a positive customer experience; his financial needs are evaluated; and he is sold a product that is suitable for his financial needs. It is difficult to measure this outcome because the bank alone cannot take responsibility for the measurement thereof. Although banks can compile customer surveys, the response rate is often poor and customers might not always communicate their discontent. Furthermore, customers might be sold a product, but never use it.

Although regulators might think that a suitable regulatory model is all that is needed to achieve a positive outcome for the customer, the reality is more complex. Various factors influence this final outcome, as shown in Figure 2 by $\mathrm{O} 1$ to $\mathrm{O} 4$ (examples of possible factors such as these will be covered in the 'Reviewing (seemingly) indirect influencing factors (Cs and Os) for effective conduct risk regulatory model' section). One of the influencing factors (shown as $\mathrm{O} 2$ ) is the full compliance with the conduct risk regulation on the part of the banks in the sense that appropriate management and mitigation techniques need to have been applied. It also means that the bank is managing conduct throughout the value chain; that processes are in place to ensure that each customer's needs are analysed and a suitable product is recommended; and that the utilisation of the product is tracked. Full compliance by the banks will be influenced by various factors, shown in Figure 2 as C1 to C4 (examples of these are presented in the 'Reviewing (seemingly) indirect influencing factors ( $\mathrm{Cs}$ and $\mathrm{Os}$ ) for effective conduct risk regulatory model" section). One of the influencing factors is likely to be a suitable regulatory model (shown as C2). A regulatory model will be suitable if it leads to a situation where banks will comply with the regulation, and if the end goal of a positive outcome for customers is achieved. The suitability of the model depends on certain influencing factors, shown in Figure 2 as M1 to M4 (some possible factors are presented in the 'Reviewing direct influencing factors (Ms) for effective conduct risk regulatory model' section). First and foremost, these factors need to be managed by the regulators as effectively as possible to achieve the end goal. Apart from this, the regulator also needs to understand, interpret and potentially influence the (independent) influencing factors of banks' compliance (Cs) and positive outcomes for customers (Os) as well. For ease of reading, Figure 2 only shows four influencing factors for each case; in reality, however, there 


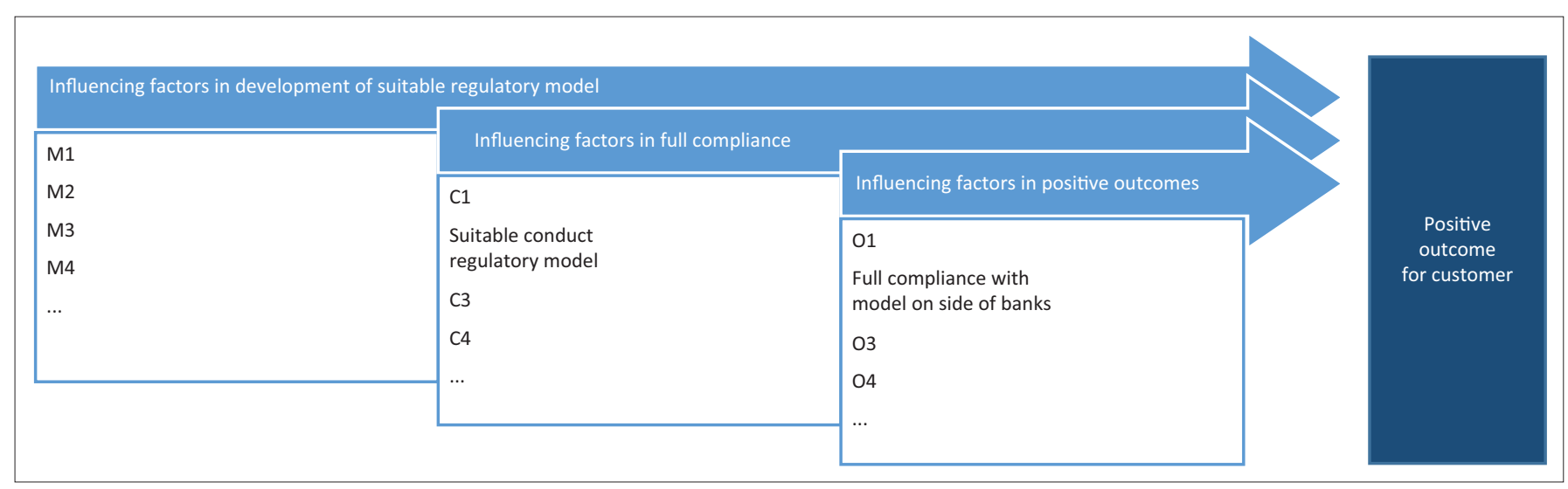

FIGURE 2: Relationships and interdependencies between influencing factors in the model.

TABLE 1: Decision-making criteria and questions (Ms).

Decision-making criteria (Ms)
Global trends for conduct regulation and influence
on country-specific approach
Financial crises and their effect on cycles of open
versus strict rule-based approaches
Socioeconomic profile and financial inclusion or
education
Cultural norms and type of enforcement
Structure of the banking sector and stakeholder
involvement
The acceptance of sustainability as a business
model
The link to other legislation already in place
The degree of product versus bank regulation

\section{Questions}

Is there a global trend on how to approach conduct regulation? If so, are there any lessons we could learn from this, or do the arguments not apply to our (country) case? Are we sharing ideas with other countries that are in a similar situation?

When did the last financial crisis happen and how did regulations change thereafter? After that, was there a trend towards more flexibility or less flexibility? After analysing these issues, what would this mean for a stable regulatory model that can function over the medium term (at least)?

What is the socioeconomic profile of our country? What is our financial inclusion and education rate? How do these issues need to be incorporated into our regulatory framework to make it suitable?

Are there any cultural norms prevalent in our country that would influence the efficacy of the approach and also the enforcement strategy to be chosen?

How much market share do the biggest banks have in our country? Will this influence our approach in the sense that we need to involve fewer stakeholders?

Do we believe that banks need to be sustainable, rather than being only profit-oriented? If not, can the model be constructed in a way in which it supports banks in finding solutions for the conflict between profit goals and ethical conduct? Do we strive for one piece of conduct risk regulation or is the legislation for conduct included in various pieces of legislation? If the latter, how can confusion and regulation-fatigue be avoided?

Are we regulating banks' behaviour or are we taking the regulation to a point where banks are limited in the products that they can design?

could be more or fewer influencing factors. Also, the factors might not be stable over time and could be subject to change.

\section{Developing an effective banking conduct risk regulatory model}

\section{Reviewing direct influencing factors (Ms) for effective conduct risk regulatory model}

Table 1 indicates possible influencing factors in the banking conduct regulatory model, based on the literature review (in the first column) and questions regulators should ask themselves to best manage those influencing factors (in the second column).

\section{Reviewing (seemingly) indirect influencing factors (Cs and Os) for effective conduct risk regulatory model}

As mentioned previously, in order for regulators to achieve the end goal of a positive outcome for the customer, they also need to examine and understand the variables shown in Table 2.

\section{Understanding the relationship between direct influencing factors (Ms) and a suitable regulatory model}

The relationship between the direct influencing factors and a suitable regulatory model is straightforward in the sense that the better the regulator's grip on the influencing factors, the
TABLE 2: Cs and Os for consideration by the regulator.

\begin{tabular}{ll}
\hline Cs and Os & Questions \\
\hline Behavioural aspects & $\begin{array}{l}\text { How can we ensure that we get buy-in for our model from } \\
\text { the various banks and - linked to this - that conduct risk is } \\
\text { implemented across the organisation and included in the } \\
\text { bank's general risk management framework? }\end{array}$ \\
$\begin{array}{ll}\text { Profit motive and } \\
\text { business model } \\
\text { Individual banks' } \\
\text { agendas }\end{array}$ & $\begin{array}{l}\text { Given the suggested regulatory model, is it possible for } \\
\text { banks to run a profitable business? }\end{array}$ \\
$\begin{array}{l}\text { Do any individual banks have an agenda of which we need } \\
\text { to be aware? If so, how can we engage with those banks } \\
\text { and remedy the situation? }\end{array}$ \\
$\begin{array}{ll}\text { Gu the regulator's } \\
\text { reaction }\end{array}$ & $\begin{array}{l}\text { How can we guide banks with regard to possible reactions } \\
\text { and sanctions (including fines) by the regulator so as to } \\
\text { enable them to manage and finance their conduct risk in a } \\
\text { more effective manner? }\end{array}$ \\
$\begin{array}{l}\text { Customer responsibility } \\
\text { and education }\end{array}$ & $\begin{array}{l}\text { How can we foster customer responsibility, considering } \\
\text { the profile of customers in our country? Who takes } \\
\text { ultimate responsibility for the customer's education - is it } \\
\text { the customer, the bank, the regulator, the government or } \\
\text { all of them? }\end{array}$ \\
$\begin{array}{l}\text { Complaints resolution } \\
\text { at national level }\end{array}$ & $\begin{array}{l}\text { Did make provision in our model for a functioning } \\
\text { complaints resolution system? How would such a system } \\
\text { need to look? }\end{array}$ \\
\hline
\end{tabular}

more suitable the regulatory model should be. Figure 3 highlights this relationship.

\section{Understanding the relationship between direct influencing factors (Cs) and full compliance on the part of the banks}

As the regulatory model becomes more and more suitable, banks' compliance should increase: the relationship should be positive. Firstly, however, as other factors (Cs) influence the compliance of banks - introduced in the 
'Reviewing (seemingly) indirect influencing factors (Cs and Os) for effective conduct risk regulatory model' section (for example, whether banks are actually willing to comply) - the relationship is not linear. Secondly, banks need to first understand what is required in terms of compliance, and so they need time to adapt. In order to ensure banks comply with ease, regulators need to attempt to influence the Cs as well, which will ideally shift the curve in the direction of the arrow, as shown in Figure 4 .

\section{Understanding the relationship between direct influencing factors (Os) and a positive outcome for customers}

Figure 5 shows that the customer outcome will be negative if minimal or no implementation occurs. The customer will be at risk. As conduct risk is managed and mitigated

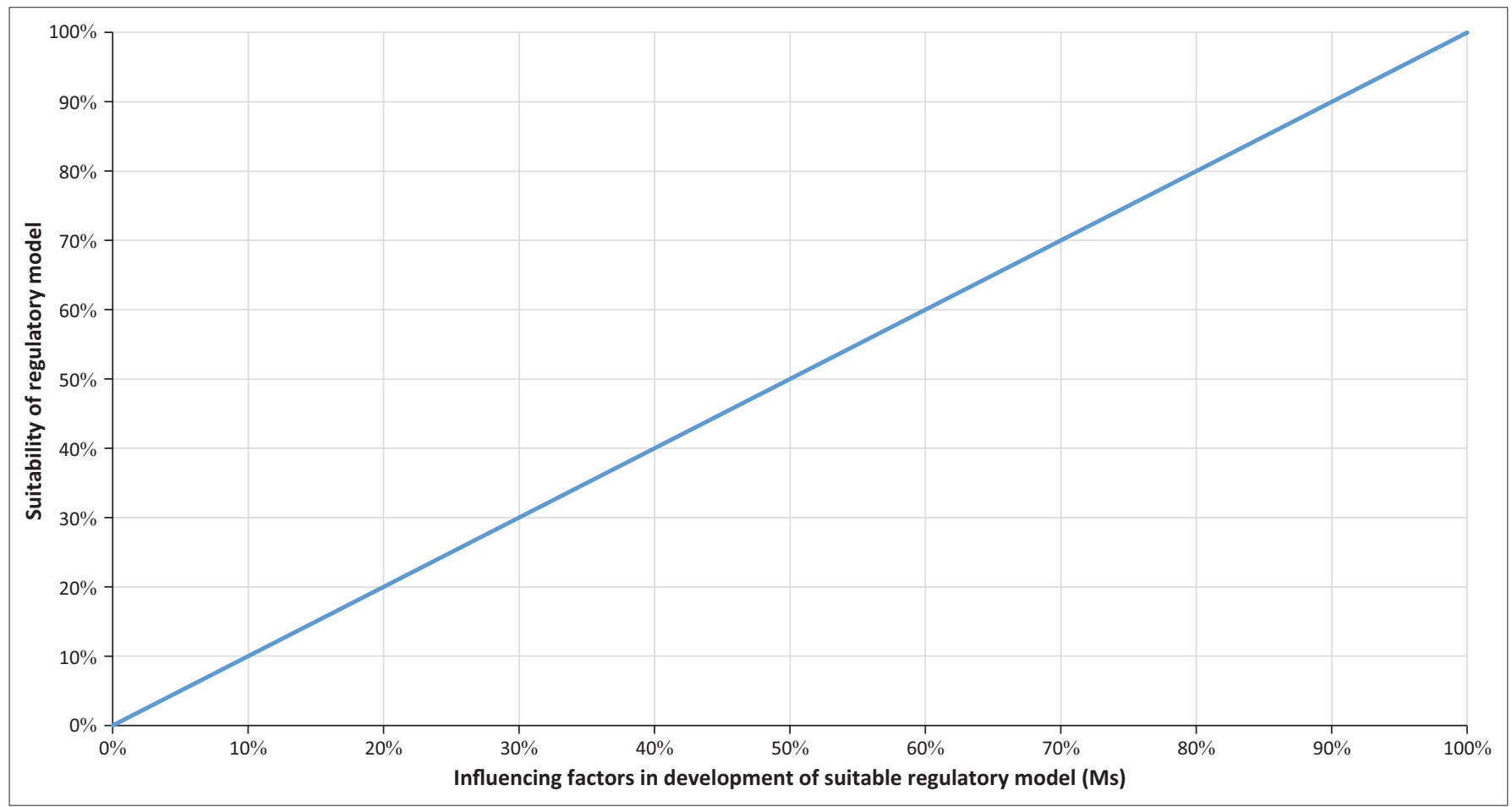

FIGURE 3: Suitability of regulatory model and the factors that influence it.

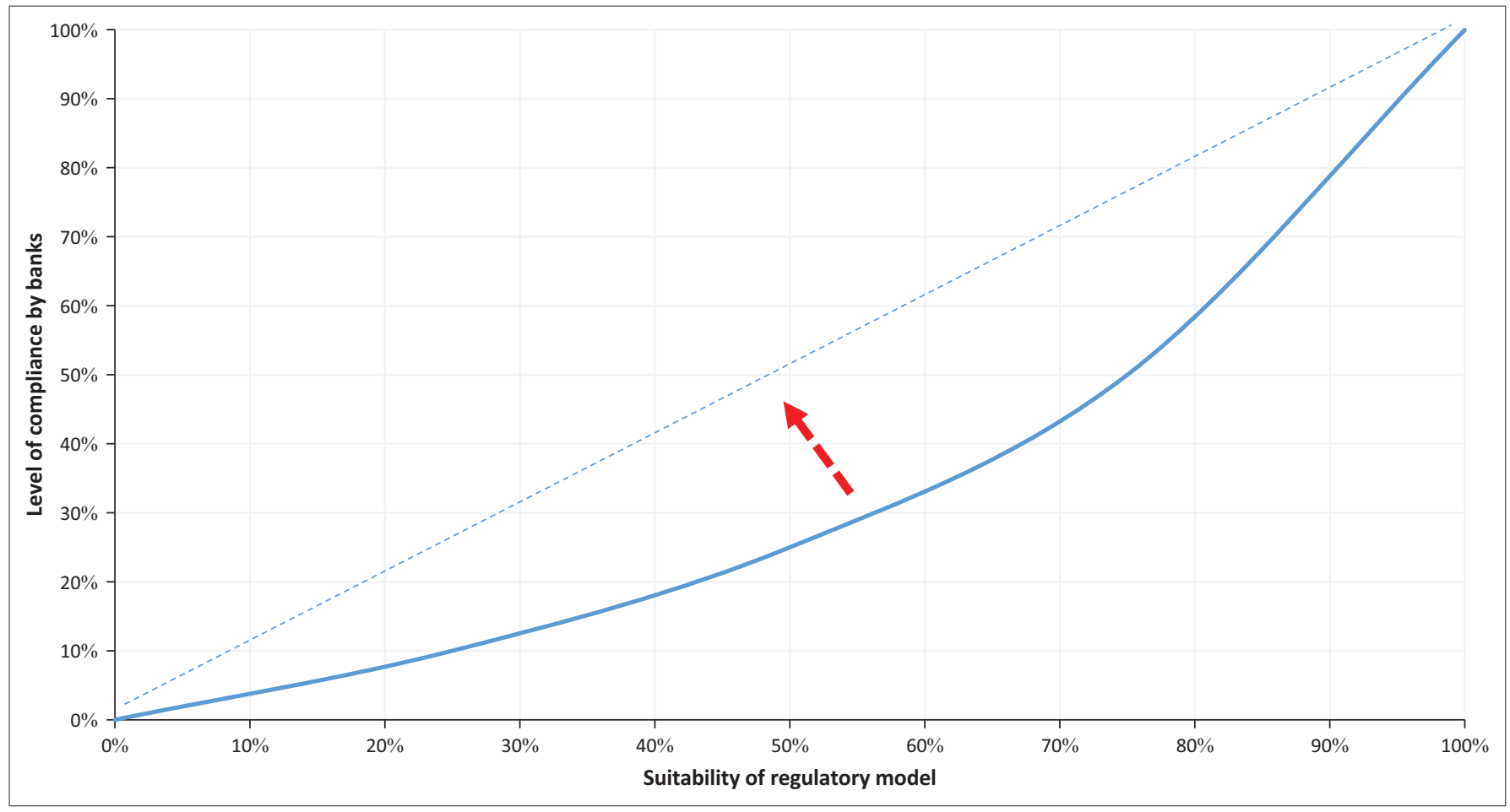

FIGURE 4: Suitability of regulatory model and level of compliance. 


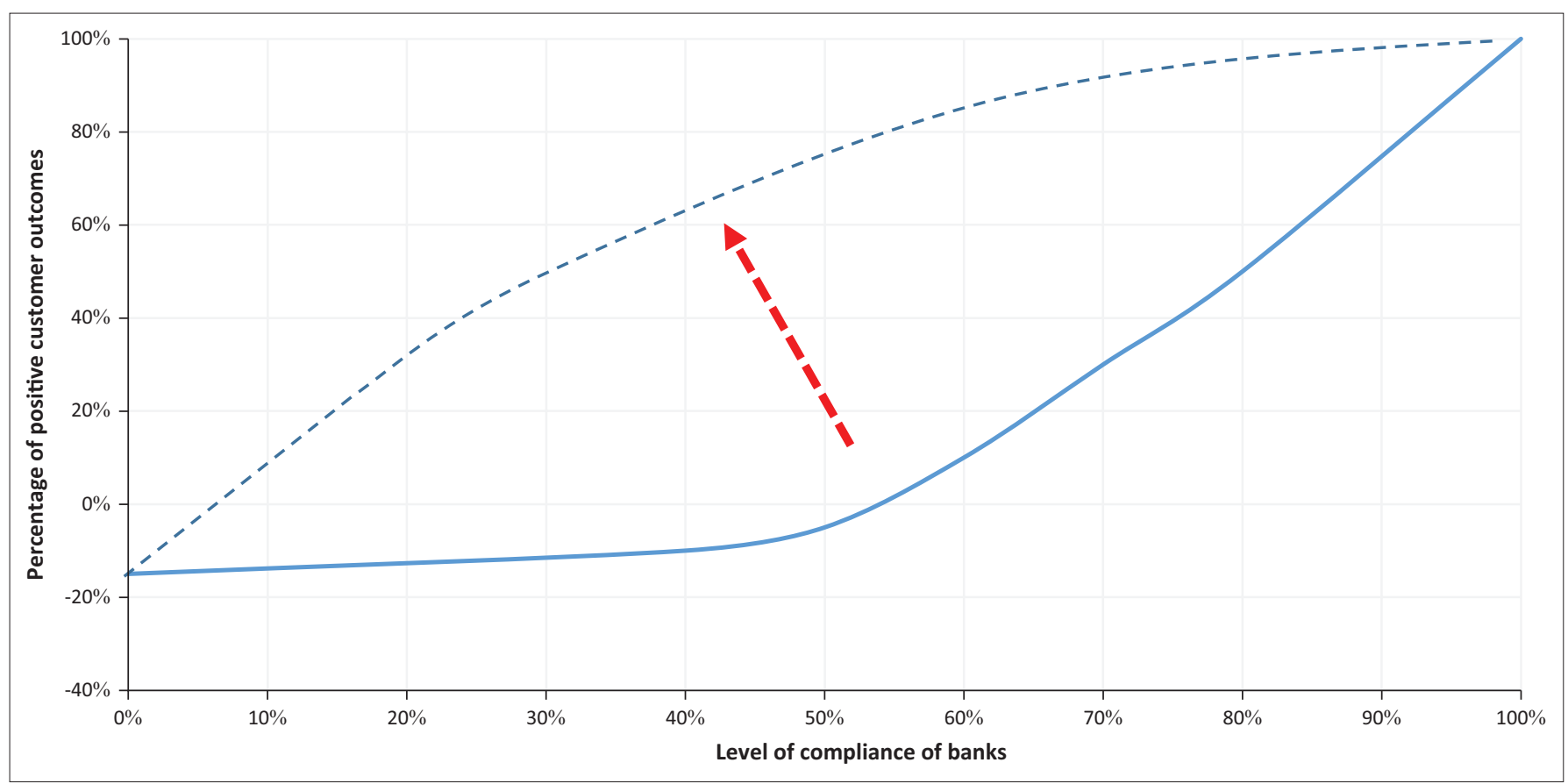

FIGURE 5: Compliance of banks versus positive customer outcome.

effectively by the bank, the customer outcome becomes more positive. However, there is a lag here: for every customer who feels a real positive impact, banks first need to perfect the implementation across the organisation for every single staff member. Regulators would need to create a model that can secure 'quick-wins' for banks in terms of compliance so that customers will feel the benefit immediately.

In their regulatory approach, regulators should make provision for banks to use existing processes and data to measure whether outcomes are positive, instead of having to 're-invent the wheel'. The more burdensome regulatory approaches and processes are, the more negative the sentiment towards compliance will be. This will result in a negative outcome for the client.

In order to shift the curve dramatically (Figure 5), regulators need to attempt to influence the other Os. The more educated customers are, and the better the complaints resolution process is, the more independent they are in terms of whether banks comply with conduct risk regulation or not. For example, if a customer is sufficiently educated about financial products, it will be more difficult for the bank employee to conduct himself unethically and sell an unsuitable product to the customer. Regulators should also attempt to create positive feedback forums, instead of only focusing on complaints resolution.

\section{The ideal world}

In an ideal world then, what results would a perfect model achieve? The perfect model would achieve $100 \%$ in all three factors, as shown in Figure 6. Somewhere in between, the customer would be sufficiently educated to not have to rely too much on conduct risk regulation. Banks would be

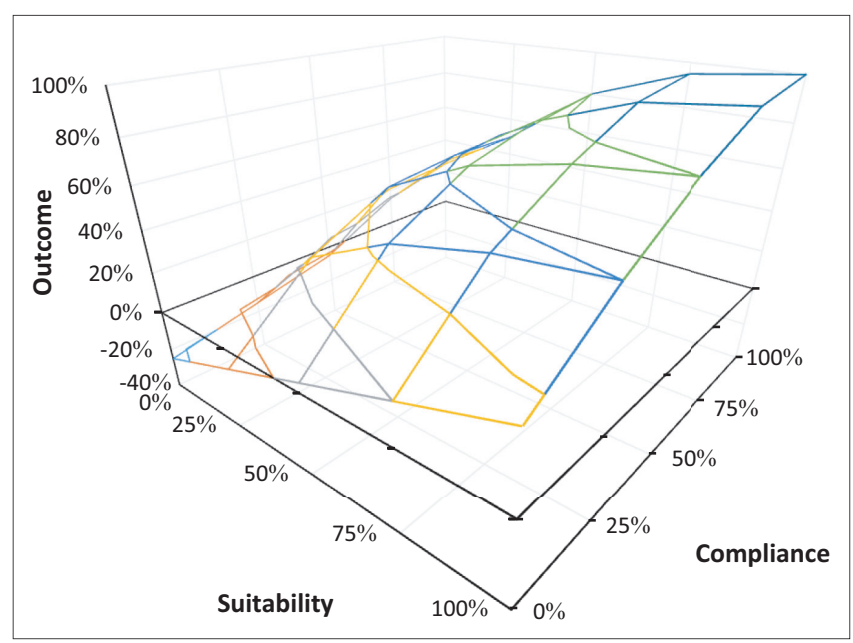

FIGURE 6: Three-dimensional graph to show regulatory model interdependencies.

convinced of the importance of conduct risk and approach its management and mitigation in the best way possible, even if the regulatory model were not as perfectly suitable. This would be partly as a result of their ability to conduct themselves accordingly, while still maintaining their profitability.

\section{Testing the model: Specific developing country examples}

Appendix A offers a detailed evaluation of whether the constructed regulatory model could work in South Africa, Malaysia and Kenya. This is presented in table format, including references - based on the model constructed in the 'Constructing an effective model for banking conduct risk regulation in developing countries' section. In Table 3, a short summary evaluation of the effectiveness of the approach of the different countries is provided. 
TABLE 3: Evaluation of assembled model using South Africa, Malaysia and Kenya as developing country examples.

\begin{tabular}{|c|c|c|}
\hline Developing country & Positives & Negatives \\
\hline South Africa & $\begin{array}{l}\text { - New planned legislation attempts to link the country's specific desired } \\
\text { economic outcomes with positive customer outcomes } \\
\text { - Government involves stakeholders in developing conduct approach } \\
\text { - Financial education is high on agenda }\end{array}$ & $\begin{array}{l}\text { - Government mainly looked at developed countries when developing } \\
\text { the conduct risk regulatory model }\end{array}$ \\
\hline Malaysia & $\begin{array}{l}\text { - Central Bank uses the concept of moral suasion in conduct risk regulation } \\
\text { - The regulators' expectations are communicated to the industry continuously } \\
\text { Deep understanding of consumer behaviour has driven financial literacy } \\
\text { and education in a major positive way, with multiple redress avenues for } \\
\text { consumers } \\
\text { - Building credibility with customers and banks alike is a priority }\end{array}$ & $\begin{array}{l}\text { - Government has a stake in most banks and seems to prioritise } \\
\text { consumers over banks, which can be viewed negatively from a free } \\
\text { market point of view } \\
\text { - The Central Bank is aware that the cost of compliance is often } \\
\text { transferred to customers, but there is no attempt by the Central Bank } \\
\text { to tackle this }\end{array}$ \\
\hline Kenya & $\begin{array}{l}\text { - Kenya has a track record for looking at country-specific requirements to } \\
\text { create conduct regulation for mobile banking providers (instead of following } \\
\text { other countries' models) }\end{array}$ & $\begin{array}{l}\text { - The challenges are slightly more pronounced, as the country has a } \\
\text { low-income profile; hence financial education cannot be relied upon } \\
\text { as yet } \\
\text { - Complaints resolution can be improved }\end{array}$ \\
\hline
\end{tabular}

\section{Conclusion and recommendations}

This research attempts to construct a model that points regulators in developing markets in the right direction. Regulators need to take challenges specific to developing markets into account. Regulators also need to influence the sentiment of the banking sector around conduct risk regulation, as well as consumer education. Lastly, it is of utmost importance that the regulatory model is set up in a way that allows banks to run profitable businesses.

Examples of three developing countries show that regulators are approaching the regulation of conduct risk in a way that is unique to each country. Country-specific issues, such as the mobile banking trends in Kenya and the low savings rate in South Africa, are influencing the way regulators think and operate.

The recommendation for regulators would be to cooperate with other developing countries in designing banking conduct risk regulation and financial education and inclusion strategies. Certain ideas could be implemented successfully in various developing market scenarios, such as introducing young schoolchildren to the study of financial education or approaching the extension of credit to lower economic profile customers in a way that ensures customers can actually afford the repayment.

Over and above this specific research, it would be interesting to explore more case examples of other developing countries, such as countries in South America, Asia and Africa. The collection of information might present challenges for some of these countries. It would be beneficial to measure the efficiency of some of the regulatory approaches to banking conduct risk in more detail once they have been implemented fully and more time has passed. Other research areas related to this specific study and worth exploring could focus on how both banks and customers have reacted to the introduction of the new conduct regulation. This could provide some direction to the banks as to how they should position themselves from a financial success and business point of view. Finally, researchers could investigate how banks prepare themselves in order to comply with conduct regulation, and whether customers will value these preparations.

\section{Acknowledgements Competing interests}

The authors declare that they have no financial or personal relationships that may have inappropriately influenced them in writing this article.

\section{Authors' contributions}

A.H. constructed the article as part of her PhD in Risk Management and G.v.V. is the supervisor and guided A.H. in all aspects of the article.

\section{References}

Alemanno, A., 2015, 'Stakeholder engagement in regulatory policy', in $O E C D$ regulatory policy outlook, 2015, viewed 24 September 2016, from http://papers. ssrn.com/sol3/papers.cfm?abstract_id=2701675.

Ali, S., 2014, 'Institutional framework on market conduct and consumer protection', Presentation at the BNM-AFI Conference in June 2014, [PowerPoint Presentation], (Unpublished).

Alliance for Financial Inclusion, 2015, 'Consumer Empowerment and Market Conduct (CEMC) working group', viewed 28 February 2015, from http://www.afi-global. org/about-us/how-we-work/about-working-groups/consumer-empowermentand-market-conduct-cemc-working-group

Azis, I.J. \& Shin, H.S., 2015, Global shock, risks, and Asian financial reform, e-book, viewed 29 March 2015, from http://UCT.eblib.com/patron/FullRecord.aspx?p= 1890461

Bank of England, 2012, 'Quarterly bulletin 2012 Q4: The prudential regulation authority', viewed 09 March 2015, from http://www.bankofengland.co.uk/ publications/Documents/quarterlybulletin/qb120405pre.pdf

Banking Association of South Africa (BASA), 2016, National Credit Act, viewed 22 September 2016, from http://www.banking.org.za/consumer-information/ legislation/national-credit-act

Barclays, 2012, 'Barclays PLC: Annual report 2012', viewed 04 February 2015, from http://reports.barclays.com/ar12/servicepages/downloads/files/entire barclays_ar12.pdf

BCBS, 2006, International convergence of capital measurement and capital standards, viewed 29 March 2015, from http://www.bis.org/publ/bcbs128.pdf

BCBS, 2011, Basel III: A global regulatory framework for more resilient banks and banking systems, viewed 29 March 2015, from http://www.bis.org/publ/bcbs189. pdf

BIS, 2014, About the Basel committee, viewed 29 March 2015, from http://www.bis. org/bcbs/about.htm

Capital Markets Authority Kenya, 2014, Capital market master plan 2014 to 2023 , viewed 29 March 2015, from http://www.cma.or.ke/index.php?option=com docman\&task=doc_download\&gid $=293 \&$ Itemid $=102$

CCP, 2016, Press release: Note on EBA 2016 stress test and conduct risk, viewed 22 September 2016, from http://foreigners.textovirtual.com/ccp-researchfoundation/271/202835/press-release-note-on-eba-2016-stress-test-andconduct-risk-6-august-2016-final.pdf

Central Bank of Kenya (CBK), 2013a, Prudential guidelines, 2013, viewed 22 March 2015, from https://www.centralbank.go.ke/images/docs/legislation/Prudential\% 20Guidelines-January\%202013.pdf

Central Bank of Kenya (CBK), 2013b, Risk management guidelines, 2013, viewed 22 March 2015, from https://www.centralbank.go.ke/images/docs/legislation/riskmanagement-guidelines-january-2013.pdf

Central Bank of Kenya (CBK), 2014, National Payment Systems Regulations 2014 viewed 20 March 2015, from https://www.centralbank.go.ke/images/docs/ legislation/NPSRegulations2014.pdf

Central Bank of Kenya (CBK), 2015, Bank supervision, viewed 20 March 2015, from https://www.centralbank.go.ke/index.php/bank-supervision 
Chen, L., Danbolt, J. \& Holland, J., 2014, 'Rethinking bank business models: The role of intangibles', Accounting, Auditing \& Accountability Journal 27(3), 563-589. https://doi.org//10.1108/AAAJ-11-2012-1153

Čihák, M. \& Podpiera, R., 2008, 'Integrated financial supervision: Which model?', The North American Journal of Economics and Finance 19(2), 135-152. https://doi. org//10.1016/j.najef.2008.03.003

Cohen, J.R., Pant, L.W. \& Sharp, D.J., 2001, 'An examination of differences in ethical decision-making between Canadian business students and accountin professionals', Journal of Business Ethics 30(4), 319-336. https://doi.org//10. 1016/j.najef.2008.03.003

Dias, D., 2013, Implementing consumer protection in emerging markets and developing economies - A technical guide for bank supervisors, viewed 17 March 2015, from http://www.cgap.org/sites/default/files/Technical-Guide-Implementing Consumer-Protection-August-2013.pdf

FCA, 2013, FCA risk outlook 2013, viewed 10 February 2015, from http://www.fca.org. uk/static/fca/documents/fca-risk-outlook-2013.pdf

FCA, 2015, 2015 fines, viewed 29 March 2015, from http://www.fca.org.uk/firms/ being-regulated/enforcement/fines

Gascoigne, B., 2001, 'History of banking', HistoryWorld, From 2001, ongoing, viewed 29 March 2015, from http://www.historyworld.net/wrldhis/PlainTextHistories. asp?historyid=ac19

International Monetary Fund (IMF), 2014, Malaysia: Financial sector assessment program, IMF country report no. 14/98, April 2014, viewed 22 March 2015, from http://www.imf.org/external/pubs/ft/scr/2014/cr1498.pdf

Irungu, G. \& Mutegi, M., 2013, 'Banks face probe by competition watchdog', Business Daily, 22 March 2013, viewed 22 March 2015, from http://www.businessdailyafrica.
com/Banks-face-probe-by-competition-watch dog/-/539552/2049072/-/ k05drcz/-/index.html

Kenya Bankers' Association (KBA), 2013a, Kenya's banks chart way forward to promote sustainable finance and build industry-wide capacity, viewed 22 March 2015 from http://www.kba.co.ke/sfi/news.htm

Kenya Bankers' Association (KBA), 2013b, About us, viewed 29 March 2015, from http://www.kba.co.ke/overview/about-us

Llewellyn, D.T., 2006, 'Institutional structure of financial regulation and supervision The basic issues', Paper presented at a World Bank seminar in Washington, DC, 6th and 7th June, viewed 23 February 2015, from http://siteresources.worldbank.org/ INTTOPCONF6/Resources/2057292-1162909660809/F2FlemmingLlewellyn.pdf

Management Solutions, 2016, Conduct risk framework: Industry trends and challenges, viewed 22 September 2016, from http://www. managementsolutions. com/PDF/ENG/Conduct-Risk-Framework.pdf

Nedbank, 2015, Long-term goals, viewed 29 March 2015, from http://www. nedbankgroup.co.za/fairshare20300urGoals.asp

Nichols, M.W., Hendrickson, J.M. \& Griffith, K., 2011, 'Was the financial crisis the result of ineffective policy and too much regulation? An empirical investigation', Journal of Banking Regulation 12(3), 236-251. https://doi.org//10.1057/jbr.2011.3.
OECD, 2011, G20 high-level principles on financial consumer protection, viewed 25 February 2015, from http://www.oecd.org/regreform/sectors/48892010.pdf

OECD, 2013, Update report on the work to support the implementation of the G20 high-level principles on financial consumer protection, viewed 25 February 2015, from www.oecd.org/g20/topics/financial-sector-reform/G20EffectiveApproaches FCP.pdf

Ojo, M., 2010, 'The growing importance of risk in financial regulation', The Journal of Risk Finance 11(3), 249-267. https://doi.org//10.1108/15265941011043639

Raj, B. \& Sindhu, 2013, 'Managing non-financial risks: Business and growth', SCMS Journal of Indian Management 10(4), 63-74.

Sepe, S., 2012, 'Regulating risk and governance in banks: A contractarian perspective', Emory Law Journal 62(1), 327-406.

South Africa. Competition Commission, 2008, Banking Enquiry Panel report makes recommendations for a more competitive banking sector, viewed 29 March 2015, from http://www.compcom.co.za/wp-content/uploads/2014/09/PR3.doc

South Africa. National Treasury, 2011, A safer financial sector to serve South Africa better', viewed 27 February 2015, from http://www.treasury.gov.za/documents/ national\%20budget/2011/A\%20safer $\% 20$ financial\%20 sector $\% 20$ to $\% 20$ serve $\% 20$ South\%20Africa\%20better.pdf

South Africa. National Treasury, 2013, Implementing a Twin Peaks model of Financial Regulation in South Africa, viewed 20 September 2016, from http://www. treasury.gov.za/twinpeaks/20131211\%20-\%20ltem\%203\%20Roadmap.pdf

South Africa. National Treasury, 2014, Treating customers fairly in the financial sector: A draft market conduct policy framework for South Africa, viewed 28 February 2015, from http://www.treasury.gov.za/public\%20comments/FSR2014/ Treating $\% 20$ Customers $\% 20$ Fairly $\% 20$ in $\% 20$ the $\% 2$ 20Financial $\% 20$ Sector $\% 20$ Draft $\% 20$ MCP\%20Framework\%20Amended $\% 20 J a n 2015 \% 20$ WithAp6.pdf

South Africa. National Treasury, 2015, 'Treating customers fairly in the financial sector: A draft market conduct policy framework for South Africa', public workshops, March 2015, [PowerPoint Presentation], (Unpublished).

Sum, K., 2016, Post-crisis banking regulation in the European Union: Opportunities and threats, Springer, London.

The World Bank, 2012, Good practices for financial consumer protection, viewed 09 March 2015, from http://responsiblefinance.worldbank.org/ /media/GIAWB/FL/ Documents/Misc/Good-practices-for-financial-consumer-protection.pdf Trochim, W.M.K., 2006, Deduction and induction, viewed 17 March 2015, from http://www. socialresearchmethods.net/kb/dedind.php

Ugeux, G., 2014, International finance regulation: The quest for financial stability, e-book, viewed 29 March 2015, from http://UCT.eblib.com/patron/FullRecord. aspx?p=1708802

United Nations Environment Programme (UNEP), 2015, UNEP environmental, social and economic sustainability framework, viewed 04 December 2015, from http:// www.unep.org/about/eses/Portals/50272/Documents/UNEP_Environmental Social_and_Economic_Sustainability_Framework.pdf 


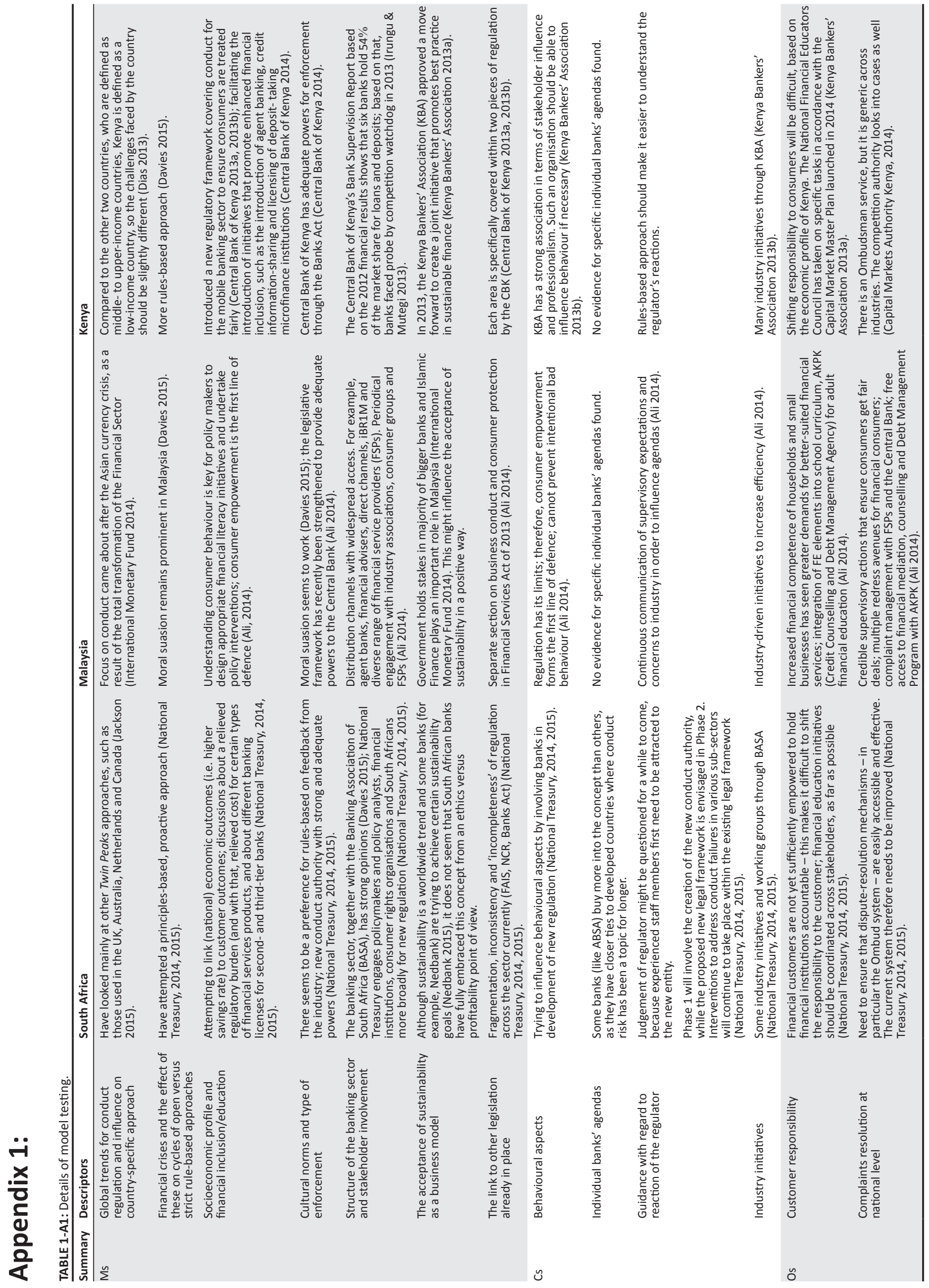


Ali, S., 2014, 'Institutional framework on market conduct and consumer protection', Presentation at the BNM-AFI Conference in June 2014, [PowerPoint Presentation] (Unpublished)

Central Bank of Kenya, 2013a, Prudential guidelines, 2013, viewed 22 March 2015, from https://www.centralbank.go.ke/images/docs/legislation/Prudential\%20 Guidelines-January\%202013.pdf

Central Bank of Kenya, 2013b, Risk management guidelines, 2013, viewed 22 March 2015, from https://www.centralbank.go.ke/images/docs/legislation/riskmanagement-guidelines-january-2013.pdf

Central Bank of Kenya, 2014, National Payment Systems Regulations 2014, viewed 20 March 2015, from https://www.centralbank.go.ke/images/docs/legislation/ NPSRegulations2014.pdf

Central Bank of Kenya, 2015, Bank supervision, viewed 20 March 2015, from https:// www.centralbank.go.ke/index.php/bank-supervision

Capital Markets Authority Kenya, 2014, Capital market master plan 2014 to 2023 , viewed 29 March 2015, from http://www.cma.or.ke/index.php?option=com docman\&task=doc_download\&gid=293\&ltemid=102

Davel, G., 2015, Conduct risk regulation in developing countries [Personal Interview] 6 March, Johannesburg.

Dias, D., 2013, Implementing consumer protection in emerging markets and developing economies - A technical guide for bank supervisors, viewed 17 March 2015, from http://www.cgap.org/sites/default/files/Technical-Guide-ImplementingConsumer-Protection-August-2013.pdf
International Monetary Fund (IMF), 2014, Malaysia: Financial sector assessment program, IMF country report no. 14/98, April 2014, viewed 22 March 2015, from program, IMF
$\mathrm{http}: / /$ www.imf.org/external/pubs/ft/scr/2014/cr1498.pdf

Irungu, G. \& Mutegi, M., 2013, 'Banks face probe by competition watchdog', Business Daily, 22 March 2013, viewed 22 March 2015, from http://www businessdailyafrica. com/Banks-face-probe-by-competition-watchdog/-/539552/2049072/-/ k05drcz/-/index.htmlJackson L.A., 2015, Conduct risk in the South African banking sector, Pers. comm., 03 February 2015.

Jackson, L.A., 2015, Conduct risk in the South African banking sector, Pers. comm., 03 February 2015.

Kenya Bankers' Association (KBA), 2013a, Kenya's banks chart way forward to promote sustainable finance and build industry-wide capacity, viewed 22 March 2015, from http://www.kba.co.ke/sfi/news.htm

Kenya Bankers' Association (KBA), 2013b, About us, viewed 29 March 2015, from http://www.kba.co.ke/overview/about-us

Nedbank, 2015, Long-term goals, viewed 29 March 2015, from http://www. nedbankgroup.co.za/fairshare20300urGoals.asp

South Africa. National Treasury, 2014, Treating customers fairly in the financial sector: A draft market conduct policy framework for South Africa, viewed 28 February 2015, from http://www.treasury.gov.za/public\%20comments/FSR2014/ Treating $\% 20$ Customers $\% 20$ Fairly $\% 20$ in $\% 20$ the $\% 20$ Financial $\% 20$ Sector $\% 20$ Draft $\% 20$ MCP\%20Framework\%20Amended\%20Jan2015\%20WithAp6.pdf

South Africa. National Treasury, 2015, 'Treating customers fairly in the financial sector: A draft market conduct policy framework for South Africa', public workshops, March 2015, [PowerPoint Presentation], (Unpublished) 